\title{
Anti-growth Effects of Imatinib and GNF5 via Regulation of Skp2 in Human Hepatocellular Carcinoma Cells
}

\section{Sung Hyun Kim ${ }^{1, *}$, Myoung-Ok Kim ${ }^{2, *}$, Ki-Rim Kim ${ }^{3}$}

${ }^{1}$ China-US (Henan) Hormel Cancer Institute, Henan, China, ${ }^{2}$ Department of Animal Science, College of Ecology and Environment Science, Kyungpook National University, ${ }^{3}$ Department of Dental Hygiene, College of Science and Technology, Kyungpook National University, Sangju, Korea

The original version of this article contained error in the Figure 1. We put wrong structure of Immatinib. We change structure of Imatinib in Figure 1 as follow.<smiles>Cc1ccc(NC(=O)c2ccc(CN3CCN(C)CC3)cc2)cc1Nc1nccc(-c2cccnc2)n1</smiles>

Imatinib<smiles>NC(=O)c1cccc(-c2cc(Nc3ccc(OC(F)(F)F)cc3)ncn2)c1</smiles><smiles>O=C(NCCO)c1cccc(-c2cc(Nc3ccc(OC(F)(F)F)cc3)ncn2)c1</smiles>

GNF2

GNF5

Figure 1. Chemical structures of imatinib, GNF2 and GNF5.

We apologize for any inconvenience that it may have caused.

Correspondence to: Ki-Rim Kim

E-mail: rim0804@knu.ac.kr, ORCID: Ki-Rim Kim, https://orcid.org/0000-0002-5967-6537

*These authors contributed equally to this work.

Copyright (C) 2019 Korean Society of Cancer Prevention

(c) This is an Open Access article distributed under the terms of the Creative Commons Attribution Non-Commercial License (http://creativecommons.org/licenses/by-nc/4.0) which permits unrestricted non-commercial use, distribution, and reproduction in any medium, provided the original work is properly cited. 